\title{
Blood Parasites in Camels (Camelus dromedarius) in Northern West Coast of Egypt
}

\section{Tarek R Abou El-Naga ${ }^{1}$ and Safaa M Barghash ${ }^{2 *}$}

${ }^{1}$ Infectious Diseases Unit, Animal Health Department, Animal Production and Poultry Division, Desert Research Center, Cairo, Egypt ${ }^{2}$ Parasitology Unit, Animal Health Department, Animal Production and Poultry Division, Desert Research Center, Cairo, Egypt

\begin{abstract}
An epidemiological study was conducted on the occurrence of blood parasitic infection in local camels in three selected sites representing Northern West Coastal zone of Egypt using Giemsa-stain blood smears (GSBS) and Polymerase chain reaction (PCR). This is the first molecular diagnosis report, which gives a picture of blood parasites covering this areas in Egypt. Results revealed that GSBS examination stopped at genus level on contrary to PCR techniques that detected and identified DNAs of blood parasites. Theileria was the most common pathogen $(50.8 \%, 71.9 \%)$, followed by Anaplasma (47.4\%, 67.37\%), Trypanosoma (20.24\%, 67.06\%), and a lesser extent Babesia $(11.8 \%, 18.43 \%)$ by GSBS and PCR, respectively. Mixed infections were present in $68.9 \%$, with at least two hemoparasites belonged to different genus. Statistical analysis showed considerable variation in values within locations and age category reflected in a high significant $(p<0.001)$, and both sexes were at risk of parasitic infections, particularly females. Only $A$. marginale caused anaplasmosis in $51(22.9 \%)$ of infected dromedaries, while the majority were having $A$. marginale together with $A$. centrale $172(77.13 \%)$. This is the first time to record B. bovis, B. bigemina, A. centrale and A. marginale in camels in this area. We concluded that blood parasites infection is highly prevalent in this area which strengthens the need to control programs help to prevent the spread of these parasites. The present results can serve as the basis for subsequent studies in dromedaries in Egypt; particularly Theileria genotype needs further studies.
\end{abstract}

Keywords: Anaplasma; Theileria; Trypanosoma; Babesia; PCR; Camels; Egypt

\section{Introduction}

Camel is an important multipurpose animal and since the old times, it has been used for transportation and produce milk, wool and meat in arid and semi-arid areas of the world [1]. Although camels are hardy animals and can tolerate the harsh conditions of arid regions because of their unique adaptive physiological characteristics, these animals face a wide variety of diseases $[2,3]$. Gastrointestinal and blood parasites are known to affect the health of camels leading to anemia, wasting and death in heavy infection [4].

Trypanosomiasis is the most important and serious pathogenic protozoal disease of camel caused by T. evansi infecting a wide range of animals throughout tropical and sub-tropical regions of the world [5-8]. Theileriosis is an important hemoparasitic disease of animals inducing a variety of clinical manifestations ranging from a subclinical presentation to a fatal disease depending, in part, on the animal species, host, age and the species of the microorganism. Tropical theileriosis caused by species of the genus Theileria has a wider distribution extending from North Africa to China [9]. Piroplasmids belonging to the genera Babesia are suspected of infecting dromedaries [10], but data published so far are limited [2,11]. The significant effect of Babesia infections are reported in domestic animals, humans, and some wildlife species. These tick-borne apicomplexan were generally considered as highly specific for a given host species [12].

Anaplasmosis is an arthropod borne disease of ruminants caused by species of the genus Anaplasma (Rickettsiales: Anaplasmataceae) [13]. Of the known Anaplasma spp., A. marginale is the most virulent, characterized by a progressive hemolytic anemia, and is responsible for extensive economic losses in tropical and subtropical areas [14-16]. On the other hand, A. centrale is capable of producing a moderate degree of anemia, but clinical outbreaks in the field are extremely rare. It is used as a live vaccine for cattle against the pathogenic $A$. marginale in tropical and subtropical areas [17]. A. marginale can be distinguished from A. centrale by the location and the characteristics of the inclusion bodies in the erythrocytes [18].

There has been a steady increase in the number of camels slaughtered for meat in Egypt. The camel's ability to utilize the scanty fodder resources of the arid and semiarid zones for body maintenance, growth and milk production makes this animal a potentially important source of food [19]. There is paucity of information on hemoparasites of camels and their significance on health and productivity in northern west coastal zone of Egypt (the main camel rearing area). Camels are largely kept without close association with other carrier animals in this area. Biting flies (Stomoxys and Tabanus), and hard ticks were noticed on several locations at the camel's body with large numbers; in particular Hyalomma dromedarii. No common use of a control program on a large scale is present. Molecular tools increasingly have become an integral part of studying the epidemiology of infectious agents. The current study was undertaken to verify the main blood parasites existing in dromedary Maghrabi camels in this area mainly by conventional PCRs.

\section{Materials and Methods}

\section{Study design and study area}

The present study was conducted on the occurrence of blood parasitic

*Corresponding author: Safaa M Barghash, Parasitology Unit, Animal Health Department, Animal Production and Poultry Division, Desert Research Center (DRC) P.O. Box 11753, Cairo, Egypt, Tel: +202- 26332846; Fax: +20 226357858; E-mail: barghash_7@yahoo.com

Received November 27, 2015; Accepted January 23, 2016; Published January 26, 2016

Citation: El-Naga TRA, Barghash SM (2016) Blood Parasites in Camels (Camelus dromedarius) in Northern West Coast of Egypt. J Bacteriol Parasitol 7: 258. doi: 10.4172/2155-9597.1000258

Copyright: (C) 2016 El-Naga TRA, et al. This is an open-access article distributed under the terms of the Creative Commons Attribution License, which permits unrestricted use, distribution, and reproduction in any medium, provided the original author and source are credited. 
Citation: El-Naga TRA, Barghash SM (2016) Blood Parasites in Camels (Camelus dromedarius) in Northern West Coast of Egypt. J Bacteriol Parasitol 7: 258. doi: 10.4172/2155-9597.1000258

Page 2 of 7

infection in local camels to detect and identify protozoan parasites, the etiological agents of trypanosomosis, theileriosis, babesiosis, and rickettsial anaplasmosis as being of economic importance. It was carried out during an epidemiological survey lasted from March 2012 to April 2015 within the frame of PROCAMED project, supported by the European Union (ENPI-Joint operational Programme of the Mediterranean Basin-IEVP-CT). For this purpose, 331 blood samples were collected randomly from local dromedary Maghrabi camels at different ages and both sexes. Diagnosis was performed primarily by Giemsa-stained blood smear (GSBS) and then analyzed mainly by different PCRs. Three sites in Matrouh governorate within the northern west coastal region of Egypt (NWC) between latitude; north $31^{\circ} 19-26^{\circ}$ 00 and longitude; $27^{\circ} 45-28^{\circ} 00$ were selected (Figure 1).

\section{Sample collection}

Whole blood samples were collected from the jugular vein of each camel using clean sterile Vacutainer tubes containing ethylene di-amine tetra acetic acid (EDTA) for (a) microscopic examination and (b) DNA extraction as a target for PCR amplification. DNA samples were stored at $-20^{\circ} \mathrm{C}$ until used. Cases of suspected trypanosomosis, theileriosis,

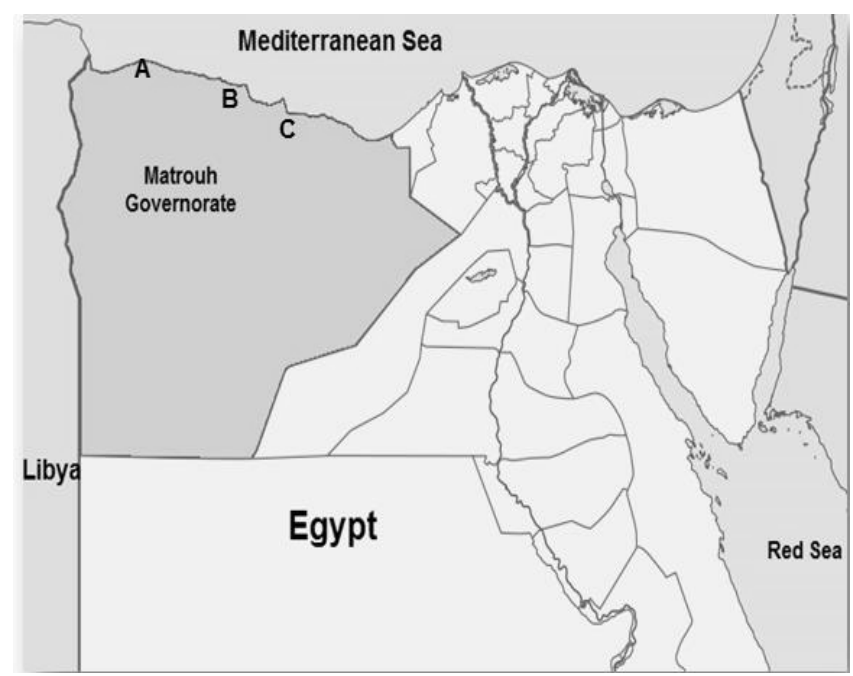

Figure 1: Map of Egypt showing North western coast where blood samples were collected from camels reared in Matrouh Governorate. A (Sidi Barrany), B (El-Negeila), C (Mersa Matrouh): are the three selected sites where blood samples were collected. anaplasmosis and babesiosis were investigated especially in Tabanus, Stomoxys and tick-infested camels with a fever, enlarged lymph nodes, anemia and jaundice, or hemoglobinuria due to Babesia.

\section{Parasitological examination}

Thin blood smears were prepared, air-dried, fixed in absolute methanol, stained with Giemsa-stain and examined microscopically for blood parasites with light microscopy (40X and oil immersion objectives) according to Hoare [20].

\section{DNA extraction and PCR amplification}

Genomic DNAs from 331 whole blood samples were extracted using The DNeasy Blood and Tissue kit (Qiagen, Hilden, Germany) according to the manufacturer's instructions. All samples were subjected to PCR based assays to detect blood parasites using species-specific primers, the details of which are shown in Table 1. PCRs were conducted in a total volume of $25 \mu \mathrm{L}$ composed of $12.5 \mu \mathrm{L}$ of commercial Master Mix (Bio-basic, Portugal), 10 pmol of each primer, 25 ng of genomic DNA and sterile water. Genomic DNAs isolated from the PCR reactions were performed in an automatic DNA thermocycler (Bio-Rad, Hercules, CA, USA) as follows: one cycle of $94^{\circ} \mathrm{C}$ for $4 \mathrm{~min}$. (Pre-denaturation), followed by $30-40$ cycles of $94^{\circ} \mathrm{C}$ for $1 \mathrm{~min}$. (denaturation). Annealing temperature was $57^{\circ} \mathrm{C}$ for $1 \mathrm{~min}$. for each of T. evansi, A. marginale, $A$. centrale, B. bigemina, B. bovis, and $52^{\circ} \mathrm{C}$ for $1 \mathrm{~min}$. for each of $T$. brucei and Theileria sp. Different annealing temperatures ranged from $47^{\circ} \mathrm{C}$ to $59^{\circ} \mathrm{C}$ were performed for Theileria annulata. Polymerization step with a final extension was one cycle of $72^{\circ} \mathrm{C}$ for $5-7 \mathrm{~min}$. PCR products were separated by $1.5 \%$ agarose gel electrophoresis to assess the presence of specific bands indicative of different blood parasites spp. [21-28].

\section{Data analysis}

Data management was performed using SPSS V20.0, (IBM SPSS Statics 20, USA). Data were summarized by descriptive statistics for mean and standard deviation. Comparisons among groups were evaluated using an analysis of variance (ANOVA) test. All statistics were considered significant at $\mathrm{p} \leq 0.05$.

\section{Results}

\section{Clinical examination}

Field clinical examination to signs related blood parasites of 331 camels revealed 256 (77.34\%) were asymptomatic and apparently healthy while $75(22.66 \%)$ camels showing some clinical abnormalities

\begin{tabular}{|c|c|c|c|}
\hline Pathogen & Nucleotide sequences of primers & (Bp) & Reference \\
\hline Anaplasma marginale & $\begin{array}{c}\text { MAR1bB2F: 5'-GCT CTA GCA GGT TAT GCG TC-3' and MAR1bB2R: 5'-CTG CTT GGG AGAATG CAC CT-3', were } \\
\text { based on Major surface protein-1 } 1 \beta \text { encoding gen }\end{array}$ & 265 & [22] \\
\hline Trypanosoma evansi & $\begin{array}{c}\text { TR3: 5'-GCGCGGATTCTTTGCAGACGA-3' and TR4: 5'- TGC AGA CAC TGG AAT GTTACT-3', were derived from } \\
\text { repetitive nucleotide sequences. }\end{array}$ & 257 & [23] \\
\hline Babesia bovis & $\begin{array}{l}\text { Bb1: 5'-TTTGGTATTTGTCTTGGTCAT -3' and B. bovis Bb2: 5'- ACC ACT GTA GTC AAA CTCACC-3', were derived } \\
\text { from the sequence of the gene encoding the enzyme carbamoyl phosphate synthetase II. }\end{array}$ & 446 & [24] \\
\hline Babesia bigemina & $\begin{array}{c}\text { Bg3: TAG TTG TAT TTC AGC CTC GCG and Bg4: AAC ATC CAA GCA GCT AHT TAG, were based on their small } \\
\text { subunit ribosomal RNA sequences. }\end{array}$ & 689 & [25] \\
\hline Theileria annulata & $\begin{array}{l}\text { In the case of } T \text {. annulata, the cytochrome b gene was selected and cytob1 primer set: Forward: } 5^{\prime}-A C T \text { TTG GCC } \\
\text { GTA ATG TTAAAC-3'/Reverse: 5'-CTC TGG ACC AAC TGT TTGG-3' was used to amplify a } 312 \text { bp variable region. }\end{array}$ & 312 & {$[26]$} \\
\hline Theileria sp. & $\begin{array}{c}\text { 989: 5'-AGT TTCTGA CCT ATC AG-3' and 990: 5'- TTG CCT TAAACT TCC TTG-3', were based on their small } \\
\text { subunit ribosomal RNA sequences. }\end{array}$ & 1100 & [27] \\
\hline Anaplasma marginale & $\begin{array}{c}\text { Am3: GTGGCAGACGGGTGAGTAATG A and Am4: CATGTCAAGAAGTGGTAAGGT, were derived from the sequence } \\
\text { of the gene encoding the surface protein. }\end{array}$ & 160 & [27] \\
\hline Trypanosoma brucei & $\begin{array}{c}\text { TBR1.2F: 5'-GAA TAT TAAACA ATG CGC AG-3' and TBR1.2R: 5'-CCA TTT ATT AGC TTT GTT GC-3' were based on } \\
\text { the highly repeated sequence of mini-chromosome satellite DNA. }\end{array}$ & 164 & [28] \\
\hline
\end{tabular}

Table 1: Nucleotide sequences of species-specific primers were used for different blood parasites detection and their expected sizes. 
Citation: El-Naga TRA, Barghash SM (2016) Blood Parasites in Camels (Camelus dromedarius) in Northern West Coast of Egypt. J Bacteriol Parasitol 7: 258. doi: 10.4172/2155-9597.1000258

Page 3 of 7

varied in their manifestation from subclinical (52/75) to clinical (23/75) (Table 2). These include weakness, depression, rough coat, emaciation, atrophy of the hump and some camels remained in sterna recumbence. The reported clinical cases are mostly associated with the recrudescence of existing infections due to stress or with the introduction of native animals raised in tick free areas into tick-infested areas. Of the 256 asymptomatic camels, $98(38.3 \%)$ and $232(90.63 \%)$ were positive by GSBS and PCR respectively, where 24 (9.38\%) were negative by either tests. None of the camel samples positive by GSBS were negative by PCR. All clinical and subclinical camels were positive by GSBS and PCR except for 5 camels were negative by microscopic examination.

\section{Parasitological findings}

Initial diagnoses by GSBS do not meet our requirements and its ability stopped at genus level, revealing four genera of parasites including Trypanosoma, Theileria, Babesia and Anaplasma. Of the 331 camels were examined for presence of blood parasites, $168(50.8 \%)$, 157 (47.4\%), 67 (20.24\%), and 39 (11.8\%) were harboring theileriosis, anaplasmosis, trypanosomosis and babesiosis, respectively (Table 3 ). Anaplasma was detected in two forms in examined camels according to the location of the inclusion bodies in the erythrocytes, while Babesia had Pear shaped like and arranged in pairs with acute or wide angles near the margin of infected erythrocytes. Theileria were detected in erythrocytes in most cases and somewhat in schizont forms.

\begin{tabular}{|c|c|c|c|c|c|c|}
\hline \multirow{2}{*}{ Camels } & \multicolumn{2}{|c|}{ Clinical examination } & \multicolumn{2}{c|}{ Blood Film } & \multicolumn{2}{c|}{ PCR } \\
\cline { 2 - 7 } & No. & $\%$ & No. & $\%$ & No. & $\%$ \\
\hline Asymptomatic & 256 & 77.34 & 98 & 38.3 & 232 & 90.63 \\
\hline Clinical & 23 & 6.95 & 23 & 100.0 & 23 & 100.0 \\
\hline Sub-clinical & 52 & 15.70 & 47 & 90.38 & 52 & 100.0 \\
\hline Total & \multicolumn{2}{|c|}{331} & 168 & $50.75^{\mathrm{a}}$ & 307 & $92.75^{\mathrm{b}}$ \\
\hline
\end{tabular}

Table 2: Detection of blood parasites in camels by microscopy and PCR based assay based on repetitive nucleotide sequences.

\section{PCR results}

PCR was the powerful method used, not only when products were not detected in DNA free samples but also describe what Trypanosoma, Anaplasma, Theileria and Babesia subspecies present. Moreover, it allowed the accurate diagnosis of mixed infections which could not be detected by GSBS. Upon using their specific primers, the expected fragments of size $257 \mathrm{bp}, 164 \mathrm{bp}, 446 \mathrm{bp}$, and $689 \mathrm{bp}$ were obtained from TR3/TR4 for T. evansi, TBR1/TBR2 for T. brucei, Bb1/ $\mathrm{Bb} 2$ for B. bovis and $\mathrm{Bg} 3 / \mathrm{Bg} 4$ for B. bigemina, respectively (Figures 2a$2 \mathrm{c}$ and 3 ). In the current study, two different species-specific primers were evaluated to detect $A$. marginale: Am3/Am4 amplified $160 \mathrm{bp}$ as expected size, whereas MAR1bB2F/MAR1bB2R could not gave the expected fragment at $265 \mathrm{bp}$, but amplified strong fragments at 519 bp with mixed infections of $A$. marginale and $A$. centrale (Figure 2b). While, $989 / 990$ the species-specific primer for Theileria detected fragments at $1100 \mathrm{bp}$, Cytob1F/Cytob1R evidenced the specificity of piroplasms infection in camels when failed to detect Th. annulata in this area (Figure 4). The presence and the percentage of blood parasites infection in Maghrabi camels in each of the three locations, both sexes and different ages are shown in Tables 2 and 3. PCR results revealed that the majorities of the detected infections were due to Theileria (71.9\%), followed by Anaplasma (67.37\%) and Trypanosoma (67.06\%) with no significant difference, then Babesia (18.43\%). The prevalence of these parasites was significantly varied between and within age groups, gender and origin of the animals $(\mathrm{p}<0.001)$, except for Theileria $(\mathrm{p}<0.05)$ (Tables 2-5). However, the higher incidence of the infected camels with protozoan parasites was found in Mersa Matrouh, the main entrance for camels from neighboring governorates, followed with slightly difference by El Negeila, and Sidi barrany that have a plenty of rains and plants than Mersa Matrouh (Table 4).

\begin{tabular}{|c|c|c|c|c|}
\hline \multirow{3}{*}{$\begin{array}{c}\text { Parasite } \\
\text { Trypanosoma }\end{array}$} & \multirow{3}{*}{$\begin{array}{c}\text { Blood smear } \\
\text { (Frequency) } \\
67(20.24 \%)\end{array}$} & \multicolumn{3}{|c|}{ PCR } \\
\hline & & \multirow{2}{*}{$\begin{array}{c}\text { Prevalence } \\
222(67.06 \%)\end{array}$} & \multicolumn{2}{|c|}{ Parasite identification (Frequency) } \\
\hline & & & $194(87.39 \%)$ T. evansi & $28(12.61 \%)$ T. brucei \\
\hline Anaplasma & $157(47.4 \%)$ & $223(67.37 \%)$ & $51(22.9 \%)$ A. marginale & $\begin{array}{c}172(77.13 \%) \\
\text { (A. } \quad \text { marginale \& A. centrale) }\end{array}$ \\
\hline Theileria & $168(50.8 \%)$ & $238(71.9 \%)$ & $238(100 \%)$ Th. camelensis & $0(0.0 \%)$ Th. annulata \\
\hline Babesia & $39(11.8 \%)$ & $61(18.43 \%)$ & $36(59.1 \%)$ B. bovis & 25 (40.9\%) B. bigemina \\
\hline
\end{tabular}

Table 3: Prevalence and identification of blood parasites in camels by Giemsa-stained blood smear and PCR based assay ( $\mathrm{n}=331$ ).
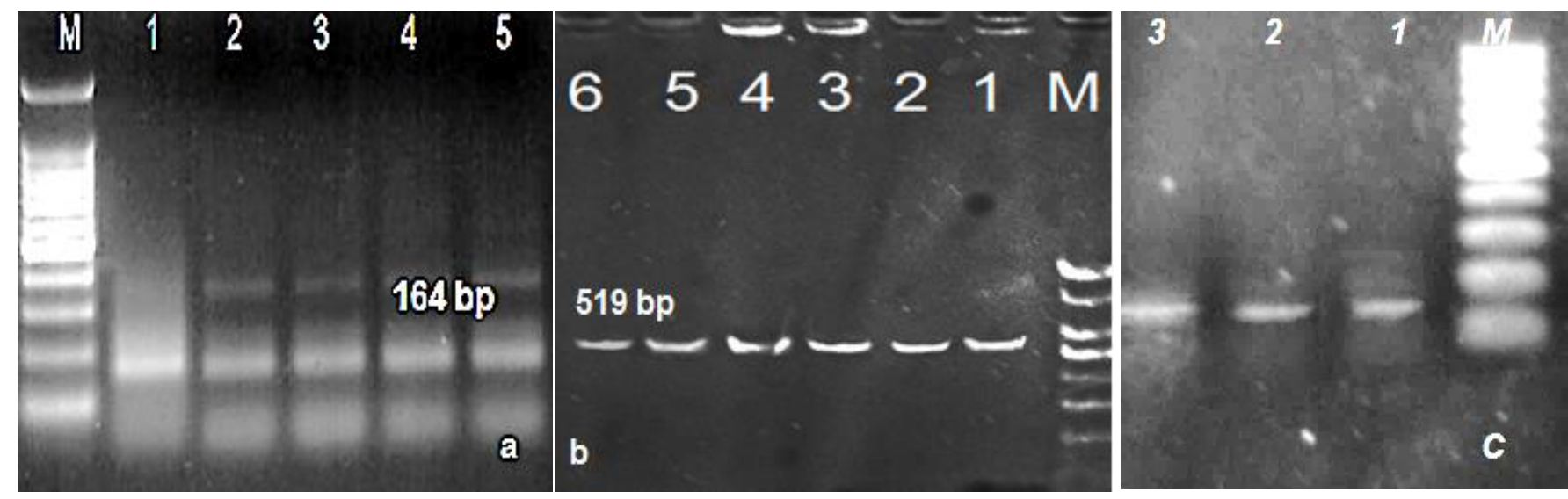

Figure 2 (a, b \& c): Results of agarose (1.5\%) gel electrophoresis of 164 bp of PCR-product for T. brucei (a), 519 bp of PCR-product for $A$. marginale together with $A$. centrale (b), and 160 bp of PCR-product for $A$. marginale only (c). Lane M, DNA molecular size marker (Qiagen, Germany). 
Citation: El-Naga TRA, Barghash SM (2016) Blood Parasites in Camels (Camelus dromedarius) in Northern West Coast of Egypt. J Bacteriol Parasitol 7: 258. doi: 10.4172/2155-9597.1000258

Page 4 of 7

\begin{tabular}{|c|c|c|c|c|c|c|c|c|c|c|c|c|c|c|c|c|}
\hline \multirow{3}{*}{$\begin{array}{c}\text { Blood } \\
\text { parasites }\end{array}$} & \multicolumn{4}{|c|}{ Sex } & \multicolumn{6}{|c|}{ Age } & \multicolumn{6}{|c|}{ Location } \\
\hline & \multicolumn{2}{|c|}{$\begin{array}{l}\text { Female } \\
(n=241)\end{array}$} & \multicolumn{2}{|c|}{$\begin{array}{c}\text { Male } \\
(n=90)\end{array}$} & \multicolumn{2}{|c|}{$\begin{array}{c}x \leq 6 \\
(n=152)\end{array}$} & \multicolumn{2}{|c|}{$\begin{array}{c}12 \geq X>6 \\
(n=84)\end{array}$} & \multicolumn{2}{|c|}{$\begin{array}{l}X>12 \\
(n=95)\end{array}$} & \multicolumn{2}{|c|}{$\begin{array}{c}\text { Mersa Matrouh } \\
(n=138)\end{array}$} & \multicolumn{2}{|c|}{$\begin{array}{l}\text { EI Negeila } \\
\quad(n=73)\end{array}$} & \multicolumn{2}{|c|}{$\begin{array}{l}\text { Sidi Barrany } \\
\quad(n=120)\end{array}$} \\
\hline & Inf. & $\%$ & Inf. & $\%$ & Inf. & $\%$ & Inf. & $\%$ & Inf. & $\%$ & Inf. & $\%$ & Inf. & $\%$ & Inf. & $\%$ \\
\hline T. evansi & 162 & 67.2 & 32 & 35.6 & 81 & 53.3 & 64 & 76.2 & 49 & 51.6 & 108 & 78.3 & 36 & 49.3 & 50 & 41.7 \\
\hline T. brucei & 22 & 9.13 & 6 & 6.7 & 12 & 7.9 & 4 & 4.8 & 12 & 12.6 & 4 & 2.9 & 10 & 13.7 & 14 & 11.7 \\
\hline Anaplasma & 152 & 63.1 & 71 & 78.9 & 105 & 69.1 & 63 & 75 & 55 & 57.9 & 108 & 78.3 & 53 & 72.6 & 62 & 51.7 \\
\hline Theileria & 172 & 71.4 & 66 & 73.3 & 106 & 69.7 & 65 & 77.4 & 67 & 70.5 & 103 & 74.6 & 53 & 72.6 & 82 & 68.3 \\
\hline Babesia & 47 & 19.5 & 14 & 15.6 & 47 & 30.9 & 4 & 4.8 & 10 & 11.1 & 44 & 31.9 & 13 & 17.8 & 4 & 3.33 \\
\hline
\end{tabular}

Table 4: Prevalence of hemoparasites were detected in camels by PCR based on sex, age and site of collection ( $n=331)$.

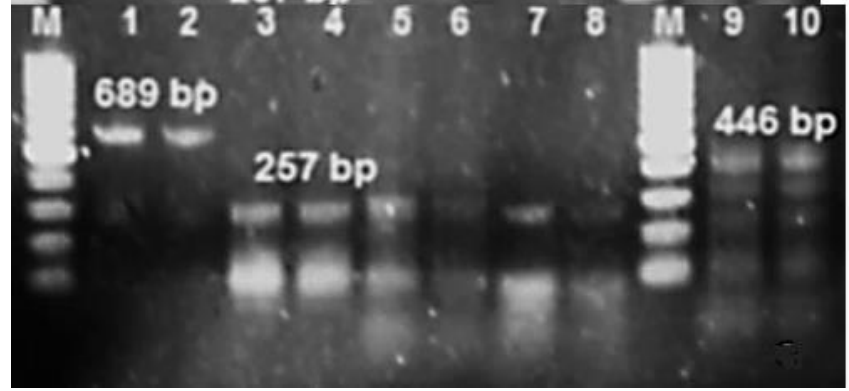

Figure 3: Ethidium bromide-stained $1.5 \%$ agarose gel electrophoresis of PCR products, Lanes M, M contained 100-bp DNA marker (Qiagen, Germany). Lanes 1, 2 contained PCR products of $B$. bigemina from camels. Lanes from 3 to 8 correspond to positive PCR products of $T$. evansi. Lanes 9,10 were PCR positive due to $B$. bovis.

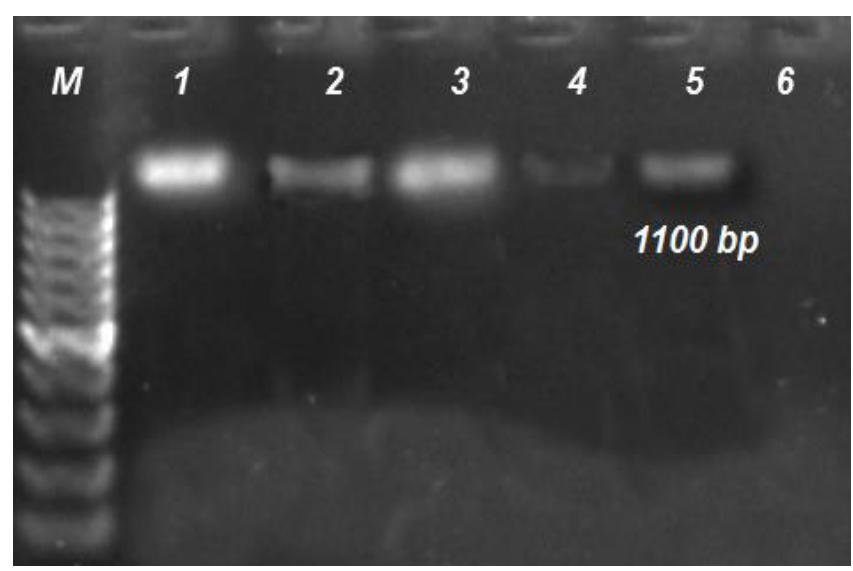

Figure 4: Agarose gel electrophoresis of amplified DNA from different Theileria species at 1100 bp by using primer set 989/990. Lanes M, molecular size marker (Qiagen, Germany). Lanes from 2 to 5 correspond to positive PCR products of Theileria $s p$. Lanes 1, 6 represent positive and negative controls, respectively.

\section{Parasite-parasite interactions (Co-infections)}

Infection with one type of disease agent can reduce or increase the incidence of infection with another. In this study, mixed infestation with different parasites from 2 to 4 in the same camel was common with a prevalence of $65.9 \%$. The overall PCR rate of mixed infection was $25.7 \%$ for two parasites, $28.1 \%$ for three parasites and $12.1 \%$ for four parasites, while $26.9 \%$ of camels were harbored one parasite and $7.25 \%$ were free from examined blood parasites as representative in Table 6 .

\section{Discussion}

Parasitic diseases have severely hindered development of livestock

\begin{tabular}{|c|c|c|c|c|c|c|}
\hline \multicolumn{7}{|c|}{ ANOVA } \\
\hline & & $\begin{array}{l}\text { Sum of } \\
\text { Squares }\end{array}$ & df & $\begin{array}{l}\text { Mean } \\
\text { Square }\end{array}$ & $\mathrm{F}$ & Sig. \\
\hline \multirow{3}{*}{ Gender } & Between Groups & 3.609 & 2 & 1.804 & 9.558 & 0.000 \\
\hline & Within Groups & 61.920 & 328 & 0.189 & & \\
\hline & Total & 65.529 & 330 & & & \\
\hline \multirow{3}{*}{ Age } & Between Groups & 17.059 & 2 & 8.530 & 12.710 & 0.000 \\
\hline & Within Groups & 220.125 & 328 & 0.671 & & \\
\hline & Total & 237.184 & 330 & & & \\
\hline \multirow{3}{*}{ T. evansi } & Between Groups & 9.405 & 2 & 4.702 & 21.756 & 0.000 \\
\hline & Within Groups & 70.892 & 328 & 0.216 & & \\
\hline & Total & 80.296 & 330 & & & \\
\hline \multirow{3}{*}{ T. brucei } & Between Groups & .751 & 2 & 0.375 & 4.947 & 0.008 \\
\hline & Within Groups & 24.881 & 328 & 0.076 & & \\
\hline & Total & 25.631 & 330 & & & \\
\hline \multirow{3}{*}{$\begin{array}{l}\text { Ana- } \\
\text { plasma }\end{array}$} & Between Groups & 4.796 & 2 & 2.398 & 11.572 & 0.000 \\
\hline & Within Groups & 67.965 & 328 & 0.207 & & \\
\hline & Total & 72.761 & 330 & & & \\
\hline \multirow{3}{*}{ Theileria } & Between Groups & .260 & 2 & 0.130 & 0.639 & 0.528 \\
\hline & Within Groups & 66.610 & 328 & 0.203 & & \\
\hline & Total & 66.870 & 330 & & & \\
\hline \multirow{3}{*}{ Babesia } & Between Groups & 5.236 & 2 & 2.618 & 19.286 & 0.000 \\
\hline & Within Groups & 44.523 & 328 & 0.136 & & \\
\hline & Total & 49.758 & 330 & & & \\
\hline
\end{tabular}

Table 5: Statistical analysis for blood parasites infections in camels based on PCR results.

\begin{tabular}{|l|c|c|c|c|c|}
\hline \multirow{2}{*}{ Prevalence } & Single & \multicolumn{3}{|c|}{ Mixed infestations } & \multirow{2}{*}{ Free } \\
\cline { 3 - 5 } & infestation & Two & Three & Four & \\
\hline No. & 89 & 85 & 93 & 40 & 24 \\
\hline Frequency & $26.9 \%$ & $25.7 \%$ & $28.1 \%$ & $12.1 \%$ & $7.25 \%$ \\
\hline
\end{tabular}

Table 6: Mixed infestations of blood parasites were detected in camels by PCR.

production in many Countries. Egypt is one of OIE Member Countries reporting blood parasitic diseases, trypanosomosis, theileriosis and babesiosis, of which trypanosomosis is the most widely distributed. The bulk of these diseases are caused by vector-borne Protozoa and Rickettsia. In the present study, camels are largely kept without close association with other carrier animals, such as cattle, sheep and goats. Consequently, transmission of blood parasites could take place at any time by biting flies and hard ticks which were noticed in large numbers; particularly $H$. dromedarii [8]. Females were-positive compared to males due to stress during gestation and milk production rendering them more susceptible to blood parasites infection [29,30]. Blood parasites infection was present in all age groups, but a group of $12 \geq$ $\mathrm{X}<6$ recorded the maximum rate of infection in all detected parasites (Table 3). This is due to owners and nomads prefer to graze their animals in open fields' where they become more exposed to vector bites, and this age group had the most performance and activity. 
Furthermore, the distribution of blood parasites in the three sites of the study area reflected their characteristic. The effective diagnosis of parasitic infections requires highly sensitive and specific tests [31]. In many cases the identification of parasites concerns their epidemiology and it is important to distinguish between species and subspecies. Piroplasms occasionally occur in blood of carrier animals but in many cases they can't be detected by direct examination, the diagnosis must be confirmed by detecting schizont [32]. Many authors did not clarify the incidence and the exact species of the blood parasite investigated camels [33]. PCR-based methods of detection have allowed prevalence data of parasites to be obtained with far greater accuracy than conventional microscopy and in some instances has taken over as the 'gold standard' for the diagnosis of parasitic infections [34].

In the present study, 60 out of 331 camels examined by GSBS, were positive for Trypanosoma (20.24\%). Nearly the same rate of infection was recorded in $16.9 \%$ of local camels and $20.9 \%$ of imported camels from Sudan at Matrouh and Aswan governorates, respectively $[8,35]$. Lower rates were recorded in different countries from time to time viz., $3.5 \%$ in Nigeria [1], 5.7\% in Egypt [31], and 4\% in Kenya [36]. On the other hand, the prevalence of T. evansi by GSBS was $29.17 \%$ at Darwa quarantine, Aswan, Egypt [37]. This variation in rates could be due to climatic variation, the diverse farming systems, abundance of vectors, and lack of health care and lack of veterinary services. Molecularly, PCR results showed that 222 out of 331 camels tested were having trypomastigotes $67.06 \%$ [194 (87.39\%) T. evansi; 28 (12.6\%) T. brucei], compared to a rate of $65.9 \%$ was recorded in the same area using RoTat1.2 amplified 205 bp [8]. Sex are likely to be risk factors for trypanosomiasis in camels in contrast to other blood parasites examined, however 162 out of $241(67.2 \%)$ females and 32 out of $90(35.6 \%)$ males were T. evansi-positive. This is coincides with two reported studies $[8,38]$. Those results were nearer to that previously recorded: $73.5 \%$ in Halaib, Shalateen and Abu-Ramad Triangle, 90\% in Siwa Oasis and 46.7\% in Maryout, Egypt [30]. In addition, our present study showed that where Mersa Matrouh recorded the highest rate of T. evansi infection $78.3 \%$, Sidi Barrany the border area between Libya and Egypt recorded the highest rate of T. brucei infection evidencing the presence of T. brucei in Egypt in 22 (9.13\%) females and $6(6.7 \%)$ males. Based on the available information, the presence of T. brucei in Egypt was monitored for the first time [39], and the presence of mixed genotyping between T. evansi isolates with T. brucei in frontiers was discussed in detail $[30,40]$.

Concerning theileriosis, it is considered to be the second most important haemoprotozoan disease following trypanosomosis affecting dromedary camels in tropical and subtropical countries [41]. In the present study, the parasite is thought to be transmitted by several species of ticks of the genus Hyalomma. However, a parallel study on tick-borne pathogens in camels (not published yet) by the same scientific team had confirmed Hyalomma species, the principal vector in the study area, has a big role in Theileria camelensis transmission among camel population. The current work indicated $50.8 \%$ of the examined camels by GSBS harbored Theileria with various developmental stages of different shapes and forms inside erythrocytes and schizont $[42,43]$. By using PCR assay, $71.9 \%$ of investigated camels were having theileriosis caused by Theileria $s p$. and the incidence of infection was $71.4 \%$ in females and $73.3 \%$ in males in agreement with those previously reported [4447]. Higher and lower rates of Theileria camelensis ranged from $6.9 \%$ to $75 \%$ were recorded in Egypt by different authors [43,46-49]. In our opinion, these variations may be attributed to nature of the study area, climatic condition, diagnosis method and animal influences. Moreover, the specificity of piroplasms infection in camels has been achieved in the present study due to absence of Th. Annulata infection despite of presence in other ruminants in the study area [50]. This is in contrast to a study provided an evidence of low host specificity of piroplasmids and the possibility that dromedaries are capable of hosting other hostspecific piroplasms [45].

Regarding anaplasmosis, there is such dearth of research on camel anaplasmosis. A. marginale is considered capable of infecting dromedaries [51], and the occurrence of subclinical anaplasmosis was addressed in dromedaries' camels [52]. In the present study, $47.4 \%$ of examined camels were harbored anaplasmosis by GSBS, while the overall infection rate recorded by PCR was $67.4 \%$ (223/331), of them, $78.9 \%$ and $63.1 \%$ were found in males and females, respectively. Anaplasma was detected in two forms belonging to A. marginale and A. centrale which were screened together in $172(77.13 \%)$ of positive samples, wherever only $A$. marginale was detected in 51 (22.9\%). These results were lower than those reported the presence of $A$. marginale in $83.8 \%$ and $95.5 \%$ of examined camels [51,53], respectively. A recent study in Nigeria showed the prevalence of hemoparasites in camels was $21.5 \%$, Anaplasma sp. was the common hemoparasites seen in examined camels, and the infection was higher in females than males $[54,55]$.

Few papers have reported Babesia sp. in camels; B. caballi was recorded for the first time in Sudanese camel [55], and the infection of Camelus dromedaries by Babesia was recorded in Egypt [47]. In the present study, 39/331 (11.8\%) and 61/331 (18.43\%) were harbored the infection with Babesia using GSBS and PCR-based assay respectively, and relatively low infections were recorded in $19.5 \%$ females and in $15.56 \%$ males. When Babesia positive samples identified by PCR-based assays, $36(59.01 \%)$ and 25 (40.9\%) of Babesia infection were found belong to $B$. bovis and B. bigemina, respectively. This means that we face problematic to cure these infected animals as they become carriers of the parasite and serve as reservoirs for transmission; in particular $B$. bovis is more dangerous than B. bigemina because it is less sensitive to some babesiacidal compounds [55]. These findings are contrary to previous studies that recorded an overall prevalence of $29 \%$ for Babesia, using PCR in Pakistan, whereby $11 \%$ were positive for B. bovis and $18 \%$ for B. bigemina [55]. In Nigeria, Babesia and Anaplasma species were the common hemoparasites seen in camels examined either singly or in combination, and more females (44.5\%) than males (34.5\%) were positive for various parasitic infections with no significant difference [54]. A recent study recorded an infection rate of $13.2 \%$ in camels in Saudi Arabia [2]. On the other hand, more recent study in Iran indicated $6.56 \%$ of camels were positive for Babesia spp. and the infection rate in males and females was $6.76 \%$ and $5.17 \%$, respectively [56].

Combined data of blood parasites infection in our study revealed that 307 out of 331 examined camels were positive (92.7\%), while 24 camels $(7.25 \%)$ were free. Mixed infection was common in the same camel (65.9\%), while $26.9 \%$ were having the infection with one parasite. A percentage of $25.7 \%$ and $28.1 \%$ were having 2 and 3 different parasites respectively, while $12.1 \%$ were infected with 4 different parasites. In our opinion, we suggest that the capacity to mount immune response against Theileria, Anaplasma and Babesia may be immunosuppressed in T. evansi infected camels in agreement with a study demonstrated that $T$. evansi infection lowers the immune-responsiveness of camels to concurrent immunizations [57].

In conclusion, it is the first time to expand our knowledge of the molecular epidemiology of parasitic infections in camels in this region except for Trypanosoma. Camels appeared to succumb to the infection 
with Theileria, Anaplasma and Trypanosoma with high rates. A. marginale and $A$. centrale were the main cause of anaplasmosis in dromedaries. This is the first report to show the presence of Babesia DNA in camels in this area. The source of infection of camels with A. marginale, B. bovis and B. bigemina might be as a result of animal movement to neighboring governorates. In addition to climates and tests, the vectors "particularly ticks" are of importance in transmission and disease management in this area. From the present study, it is clear that we face a big problem needed to reevaluated, especially the first infection with blood parasite may make the host more likely to acquire the second.

\section{Acknowledgement}

The authors gratefully acknowledge the financial support from the Desert Research Center (DRC). This study was partially funded by the European Union (ENPI-Joint operational Programme of the Mediterranean Basin -IEVP-CT), in the frame of PROCAMED project. This work was supported by Desert Research Center (DRC), Egypt. Authors would like to thank Mr. Esam A. Razin, Animal Health Department, DRC, Egypt for statistical analysis.

\section{References}

1. Kamani J, Usman TA, Onyeamaechi EG, Usman MA, Kida SM, et al. (2008) Hemoparasites of camels (Camelus dromedarius) in Maiduguri, Nigeria. Anim Res Int 5: 838-839.

2. Swelum AA, Ismael AB, Khalaf AF, Abouheif MA (2014) Clinical and laboratory findings associated with naturally occurring babesiosis in dromedary camels. Bull Vet Inst Pulaway 58: 229-233

3. Karimi A, Rahbari S, Yousefi A (2014) Blood parasites of camels from central regions of Iran: comparative evaluation of various detection techniques and serum protein components. J Adv Parasitol 2: 1-4.

4. Mahran OM (1989) Some studies on Blood Parasites in Camels (Camelus dromedarius) at Shalatin City, Red Sea Governorate. J Eukaryot Microbiol 36 $422-423$

5. Hilali M, Abdel-Gawad A, Nassar A, Abdel-Wahab A, Magnus E, et al. (2004) Evaluation of the card agglutination test (CATT/T. evansi) for detection of Trypanosoma evansi infection in water buffaloes (Bubalus bubalis) in Egypt. Vet Parasitol 121: 45-51.

6. Abdel-Rady A (2008) Epidemiological studies (parasitological, serological and molecular techniques) of Trypanosoma evansi infection in camels (Camelus dromedarius) in Egypt. Vet World 1: 325-328.

7. Gillingwater K, Büscher P, Brun R (2007) Establishment of a panel of reference Trypanosoma evansi and Trypanosoma equiperdum strains for drug screening. Vet Parasitol 148: 114-121.

8. Barghash SM, Abou El-Naga TR, El-Sherbeny EA, Darwish AM (2014) Prevalence of Trypanosoma evansi in Maghrabi Camels (Camelus dromedarius) in Northern-West Coast, Egypt using Molecular and Parasitological Methods. Acta Parasitol Glob 5: 125-132.

9. Mukhebi AW, Perry BD, Kruska R (1992) Estimated economics of theileriosis control in Africa. Prev Vet Med 12: 73-85.

10. Egbe-Nwiyi TN, Chaudry SUR (1994) Trypanosomosis: Prevalence and pathology of camel of arid zone of north eastern Nigeria. Pakistan Veterinary Journal 14: 24-27.

11. Al-Khalifa MS, Hussein HS, Diab FM, Khalil GM (2009) Blood parasites of livestock in certain Regions in Saudi Arabia. Saudi J Biol Sci 16: 63-67.

12. Uilenberg G (2006) Babesia-a historical overview. Vet Parasitol 138: 3-10.

13. Kocan KM, De La Fuente J, Blouin EF, Garcia-Garcia JC (2004) Anaplasma marginale (Rickettsiales: Anaplasmataceae): recent advances in defining hostpathogen adaptations of a tick-borne rickettsia. Parasitol 129: 285-300.

14. Wernery U, Kaaden OR (2002) Infectious diseases of camelids, Blackwell Science, Berlin.

15. Silveira JA, Rabelo EM, Ribeiro MF (2012) Molecular detection of tickborne pathogens of the family Anaplasmataceae in Brazilian brown brocke deer (Mazama gouazoubira, Fischer, 1814) and marsh deer (Blastocerus dichotomus, Illiger, 1815). Transbound Emerg Dis 59: 353-360.
16. Hairgrove T, Schroeder ME, Budke CM, Rodgers S, Chung C, et al. (2015) Molecular and serological in-herd prevalence of Anaplasma marginale infection in Texas cattle. Prev Vet Med 119: 1-9.

17. Carelli G, Decaro N, Lorusso E, Paradies P, Elia G, et al. (2008) First report of bovine anaplasmosis caused by Anaplasma centrale in Europe. Ann N Y Acad Sci 1149: 107-110.

18. Ristic M, Kreier JP (1984) Family III. Anaplasmataceae Phillip 1957. In Bergey's Manual of Systematic Bacteriology (Vol. I) Kreig JG, Hoh JG (eds.) Williams \& Wilkins, Baltimore, USA, pp. 719-729.

19. Knoess KH (1977) The camel as a meat and milk animal. World Anim Rev 22 3-8.

20. Hoare CA (1972) The trypanosomes of mammals, In: A Zoological Monograph Blackwell Scientific Publications, Oxford, UK, pp. 1-749.

21. Bilgiç HB, Karagenç T, Simuunza M, Shiels B, Tait A, et al. (2013) Development of a multiplex PCR assay for simultaneous detection of Theileria annulata Babesia bovis and Anaplasma marginale in cattle. Exp Parasitol 133: 222-229.

22. Wuyts N, Chokesajjawatee N, Panyim S (1994) A simplified and highly sensitive detection of Trypanosoma evansi by DNA amplification. Southeast Asian J Trop Med Public Health 25: 266-271.

23. Chansiri K, Bagnara AS (1995) The structural gene for carbamoyl phosphate synthetase from the protozoan parasite Babesia bovis. Mol Biochem Parasitol 74: $239-243$.

24. Ellis J, Hefford C, Baverstock PR, Dalrymple BP, Johnson AM (1992) Ribosoma DNA sequence comparison of Babesia and Theileria. Mol Biochem Parasitol 54: $87-95$.

25. Bilgic HB, Karagenç T, Shiels B, Tait A, Eren H, et al. (2010) Evaluation of cytochrome $b$ as a sensitive target for PCR based detection of $T$. annulata carrier animals. Vet Parasitol 174: 341-347.

26. Figueroa JV, Chieves LP, Johnson GS, Buening GM (1993) Multiplex polymerase chain reaction based assay for detection of Babesia bigemina, Babesia bovis and Anaplasma marginale DNA in bovine blood. Vet Parasitol 50: 69-81.

27. Masiga DK, Smyth AJ, Hayes P, Bromidge TJ, Gibson WC (1992) Sensitive detection of trypanosomes in tsetse flies by DNA amplification. Int J Parasito 22: 909-918.

28. Shah SR, Phulan MS, Memon MA, Rind R, Bhatti WM (2004) Trypanosomes infection in Camels. Pak Vet J 24: 209-210.

29. Barghash SM (2010) Study of genetic variability and prevalence of Trypanosoma evansi in domestic animals in Egypt.

30. Zayed AA, Habeeb SM, Allam NAT, Ashry HMZ, Mohamed AHM, et al. (2010) A critical comparative study of parasitological and serological differential diagnostic methods of Trypanosoma evansi infections in some farm animals in Egypt. Am-Eurasian J Agric \& Environ Sci 8: 633-642.

31. Ali AEF, Radwan MEI (2011) Molecular detection of Theileria Annulata in Egyptian buffaloes and biochemical changes associated with particular oxidative changes. Adv Life Sci 1: 6-10.

32. Ambrosio RE, de Waal DT (1990) Diagnosis of parasitic disease. Rev Sci Tech 9: 759-778.

33. Vega-López F (2003) Diagnosis of cutaneous leishmaniasis. Curr Opin Infect Dis 16: $97-101$.

34. El-Hewairy HM, Sahar A, Galal A, Mousa WM (2014) New approach for diagnosis of Trypanosomes evansi in camel (Camelus dromedaries) by ELISA. Life Sci J 11(X).

35. Chemuliti JK, Gathura PB, Kyule MM, Njeruh FM (2002) Bacteriologica qualities of indoor and out-door drinking water in Kibera sub-location of Nairobi, Kenya. East Afr Med J 79: 271-273.

36. Ra'ouf MA (2008) Studies on some parasitic affections in imported camel at Darwa quarantine, Aswan, Egypt. Beni-Suef University.

37. Bhutto B, Gadahi JA, Shah G, Dewani P, Arijo AG (2010) Field investigation on the prevalence of trypanosomiasis in camels in relation to sex, age and herd size. Pak Vet J 30: 175-177.

38. Barghash SM (2005) Molecular studies on Trypanosoma evansi infecting 
Citation: El-Naga TRA, Barghash SM (2016) Blood Parasites in Camels (Camelus dromedarius) in Northern West Coast of Egypt. J Bacteriol Parasitol 7: 258. doi: 10.4172/2155-9597.1000258

camels and other susceptible animals in Egypt. Faculty of Science, Ain Shams University.

39. Abou El-Naga TR, Barghash SM, Abdel-Hafez HM, Ashour AA, Salama MS (2012) Evaluation of (RoTat 1.2-PCR) assays for identifying Egyptian Trypanosoma evansi DNA. Acta Parasitol Glob 3: 01-06.

40. Mazyad SA, Khalaf SA (2002) Studies on theileria and babesia infecting live and slaughtered animals in Al Arish and El Hasanah, North Sinai Governorate Egypt. J Egypt Soc Parasitol 32: 601-610.

41. Salim Abadi Y, Telmadarraiy Z, Vatandoost H, Chinikar S, Oshaghi M, et al. (2010) Hard Ticks on Domestic Ruminants and their Seasonal Population Dynamics in Yazd Province, Iran. Iran J Arthropod Borne Dis 4: 66-71.

42. Hamed MI, Zaitoun AMA, El-Allawy TAA, Mourad MI (2011) Investigation of Theileria camelensis in camels infested by Hyalomma dromedarii ticks in Upper Egypt. Adv Vet Res 1: 4-7.

43. Abdel-Wahab AM (2005) Studies on Trypanosoma species infecting equines in Egypt. Faculty of Veterinary Medicine, Cairo University.

44. Qablan MA, Sloboda M, Jirků M, ObornÃk M, Dwairi S, et al. (2012) Quest for the piroplasms in camels: identification of Theileria equi and Babesia caballi in Jordanian dromedaries by PCR. Vet Parasitol 186: 456-460

45. Youssef SY, Yasien S, Mousa WM, Nasr SM, El-Kelesh EA, et al. (2015) Vector identification and clinical, hematological, biochemical, and parasitological characteristics of camel (Camelus dromedarius) theileriosis in Egypt. Trop Anim Health Prod 47: 649-656.

46. Abd-Elmaleck BS, Abed GH, Mandourt AM (2014) Some Protozoan Parasites Infecting Blood of Camels (Camelus dromedarius) at Assiut Locality, Upper Egypt. J Bacteriol Parasitol 5:184.

47. Abou-Elnaga TR, Mahmoud MA, Osman WA, Goda ASA (2009) Serological survey of Anaplasma marginale (Rickettsia) antibodies in animals by major surface protein 5 competitive inhibition Enzyme-linked Immunosorbent Assay. SCVMJ, IVX 1: 309-320.
48. Mahmoud MA, Amin MM, Youssef RR, El-Kattan A, Azza SA, et al. (2008) Studies on some endoparasites of camels in the Southeastern area of Egypt SCVMJ XIII: 81-92.

49. Gebely MAM (2004) Prevalence of some parasitic diseases in small ruminants in Siwa Oasis. Cairo University, Egypt.

50. AISaad KM, Al-Obaidi QT, Esmaeel SA (2009) Hematological and biochemical study on the effect some common blood parasites in native goats in Mosul area. Iraqi Journal of Vet Sci 23: 101-106.

51. Sudan V, Sharma RL, Borah MK (2014) Subclinical anaplasmosis in camel (Camelus dromedarius) and its successful therapeutic management. J Parasit Dis 38: 163-165

52. Ghafar MW, Shobrak MY (2014) Molecular detection and characterization of Anaplasma phagocytophilum, the causative agent of human granulocytic anaplasmosis, in some animals suspected to be competent reservoirs in Taif district, Kingdom of Saudi Arabia. Life Sci J 11: 63-69.

53. Rabana JL, Kumshe HA, Kamani J, Hafsat G, Turaki UA, et al. (2011) Effects of parasitic infections on erythrocyte indices of camels in Nigeria. Vet Res Forum 2: 59-63.

54. Abdelrahim IA, Ismail AA, Majiid AM, Mohammed AS, Ibrahim AM (2009) Detection of Babesia caballi in the one-humped Camel (Camelus dromedaries) using the Reverse Line Block (RLB) in Sudan. Sudan J Vet Res 24: 69-72.

55. Chaudhry ZI, Suleman M, Younus M, Aslim A (2010) Molecular detection of Babesia bigemina and Babesia bovis in crossbred carrier cattle through PCR. Pak J Zool 42: 201-204.

56. Khamesipour F, Doosti A, Koohi A, Chehelgerdi M, Mokhtari-Farsani A, et al (2015) Determination of the presence of Babesia DNA in blood of cattle, came and sheep in Iran by PCR. Arch Biol Sci Belgrade 67: 83-90.

57. Holland WG, Do TT, Huong NT, Dung NT, Thanh NG, et al. (2003) The effect of Trypanosoma evansi infection on pig performance and vaccination against classical swine fever. Vet Parasitol 111: 115-123. 